\title{
Tuning Nitrogen Species and Content in Carbon Materials through Constructing Variable Structures for Supercapacitors
}

\author{
SUN Peng ${ }^{1,2}$, ZHANG Shaoning $^{1,3}$, BI Hui ${ }^{1}$, DONG Wujie ${ }^{1}$, HUANG Fuqiang ${ }^{1,3,4}$
}

(1. State Key Laboratory of High Performance Ceramics and Superfine Microstructure, Shanghai Institute of Ceramics, Chinese Academy of Sciences, Shanghai 200050, China; 2. Center of Materials Science and Optoelectronics Engineering, University of Chinese Academy of Sciences, Beijing 100049, China; 3. School of Physical Science and Technology, ShanghaiTech University, Shanghai 200031, China; 4. State Key Laboratory of Rare Earth Materials Chemistry and Applications, College of Chemistry and Molecular Engineering, Peking University, Beijing 100871, China.)

\begin{abstract}
Carbon materials are favorable for supercapacitors but suffer from insufficient capacitance. Heteroatom doping, especially nitrogen $(\mathrm{N})$ doping, is an effective method to significantly improve the electrochemical performance, but it is still a big challenge to achieve high active nitrogen content in carbon materials. This work successfully tuned nitrogen species and content by interaction between $\mathrm{Si}-\mathrm{O}-\mathrm{Si}$ network and aluminum oxide. Besides, the structure of carbon materials varies from a coral-like network to three-dimensional structure by adjusting the precursor composition. Oxygen $(\mathrm{O})$ in oxides bonds with $\mathrm{N}$ in carbon materials during the reaction, which makes it difficult to escape, achieving high nitrogen content of 5.29 at $\%$ at $1000{ }^{\circ} \mathrm{C}$. On the other hand, the interaction empowers the carbon material with large pore volume of $\sim 1.78 \mathrm{~cm}^{3} \cdot \mathrm{g}^{-1}$ and broad pore size distribution

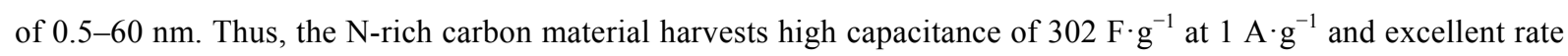
capability of $177 \mathrm{~F} \cdot \mathrm{g}^{-1}$ at $120 \mathrm{~A} \cdot \mathrm{g}^{-1}$. This unique nitrogen fixation method is a promising strategy for preparing high performance electrode materials of supercapacitors.
\end{abstract}

Key words: carbon material; nitrogen fixation; interaction; morphology design; supercapacitor

Currently, carbon materials are the promising electrode materials in supercapacitors due to its outstanding electrical conductivity, high surface area, extraordinary electrochemical stability and low cost ${ }^{[1-3]}$. Nevertheless, the specific capacitance of commercial activated carbon is about $200 \mathrm{~F} \cdot \mathrm{g}^{-1}$, falling short of the practical applications ${ }^{[4]}$. Heteroatom doping (e.g., $\mathrm{N}, \mathrm{P}$ and $\mathrm{S}$ ) is an efficient approach to improve the capacitance $\mathrm{e}^{[5-6]}$. Among different $\mathrm{N}$ doping types, pyridinic nitrogen $(\mathrm{N}-6)$ and pyrrolic nitrogen (N-5) are effectively active sites, which can provide much pseudocapacitance. Hence, how to achieve high active nitrogen content in carbon materials is the key issue for next generation supercapacitors.

Two methods are proposed in recent works. One common way is to lower the pyrolysis temperature at the cost of conductivity loss ${ }^{[7-8]}$. Generally, low-temperature pyrolysis leads to high nitrogen content in the carbon materials, because the increasing sintering temperature enhances the graphitization degree, reduces the defects and edge sites. The other approach is to dope phosphorus to adjust the active $\mathrm{N}$ proportion but not total nitrogen conten ${ }^{[9-10]}$. Previous work suggests that P-doping could result in high distortion of carbon structures, consequently producing defects and open edge sites in the $\mathrm{N}$-doped carbon materials ${ }^{[10]}$. The defects and edge sites in the carbon materials play important roles in achieving a high proportion of pyridinic-N. Therefore, the construction of N-rich carbon materials with high electrical conductivity is extremely challenging.

Herein, we designed the $\mathrm{N}$-rich carbon material by introducing both $\mathrm{Si}-\mathrm{O}-\mathrm{Si}$ network and aluminum oxide at $1000{ }^{\circ} \mathrm{C}$ for supercapacitors. The interaction between $\mathrm{Si}-\mathrm{O}-\mathrm{Si}$ network and aluminum oxide can promote the activity of oxygen atoms in oxides, making $\mathrm{O}$ in oxides

Received date: 2020-08-27; Revised date: 2020-10-20; Published online: 2020-11-05

Foundation item: National Key Research and Development Program of China (2016YFB0901600); National Natural Science Foundation of China (51972326, 51672295, 21871008, 51672301); Science and Technology Commission of Shanghai (18YF1427200); The Key Research Program of Chinese Academy of Sciences (QYZDJ-SSW-JSC013)

Biography: SUN Peng (1992-), male, PhD candidate. E-mail: sunpeng@student.sic.ac.cn

孙 鹏(1992-), 男, 博士研究生. E-mail: sunpeng@student.sic.ac.cn

Corresponding author: HUANG Fuqiang, professor. E-mail: huangfq@mail.sic.ac.cn 黄富强, 研究员. E-mail: huangfq@mail.sic.ac.cn 
bond with $\mathrm{N}$, main active $\mathrm{N}$ in carbon, which is beneficial for achieving high nitrogen content. Additionally, the $\mathrm{Si}-\mathrm{O}-\mathrm{Si}$ network and aluminum oxide as templates also empower the carbon material with large pore volume, 3D interconnected and hierarchical porous structure. Thus, these features lead to the excellent performance for supercapacitors with this N-rich carbon material.

\section{Experimental}

\subsection{Sample preparation}

\subsubsection{Preparation of precursors}

All reagents were of analytical grade and used without any purification. In a typical synthesis, $2 \mathrm{~g}$ of triblock copolymer polyethylene oxide-polypropylene oxidepolyethylene oxide (PEO-PPO-PEO) (P-123) as the surfactant, $1 \mathrm{~mL}$ of pyrrole as the nitrogen and carbon source, $3 \mathrm{~g}$ of $\mathrm{Al}\left(\mathrm{NO}_{3}\right)_{3} \cdot 9 \mathrm{H}_{2} \mathrm{O}$ or $4 \mathrm{~mL}$ of tetraethyl orthosilicate (TEOS) was added, respectively, or both $\mathrm{Al}\left(\mathrm{NO}_{3}\right)_{3} \cdot 9 \mathrm{H}_{2} \mathrm{O}$ and TEOS were added. Then, $0.4 \mathrm{~mL}$ of $1 \mathrm{~mol} \cdot \mathrm{L}^{-1} \mathrm{HCl}$ and $50 \mu \mathrm{L}$ of $\mathrm{FeCl}_{3}\left(50 \mathrm{mg} \cdot \mathrm{mL}^{-1}\right)$ were continuously dissolved in $10.0 \mathrm{~mL}$ of ethanol. Finally, the solution was kept at $60{ }^{\circ} \mathrm{C}$ in oven overnight. For comparison, the gel without TEOS and $\mathrm{Al}\left(\mathrm{NO}_{3}\right)_{3} \cdot 9 \mathrm{H}_{2} \mathrm{O}$, was prepared by the above procedure.

\subsubsection{Preparation of variable-structure carbon materials}

The precursors were ground into powders, and heated under $\mathrm{H}_{2}(20 \mathrm{sccm})$ and $\mathrm{Ar}(300 \mathrm{sccm})$ flows at $1000{ }^{\circ} \mathrm{C}$ (heating rate: $10{ }^{\circ} \mathrm{C} \cdot \mathrm{min}^{-1}$ ) for $2 \mathrm{~h}$. The furnace was cooled to $400{ }^{\circ} \mathrm{C}$ at $10{ }^{\circ} \mathrm{C} \cdot \mathrm{min}^{-1}$ before natural cooling to the room temperature. The residual oxides were removed in a mixed solution of $6 \mathrm{~mol} \cdot \mathrm{L}^{-1} \mathrm{H}_{3} \mathrm{PO}_{4}$ and $8 \mathrm{~mol} \cdot \mathrm{L}^{-1} \mathrm{HF}$ to obtain the carbon materials. To improve electrochemical performance, $\mathrm{N}$ doping was promoted by providing $\mathrm{NH}_{3}$ flow (100 sccm) in the heating process. The prepared carbon materials were denoted as $\mathrm{NC}$ (without the addition of $\mathrm{Al}\left(\mathrm{NO}_{3}\right)_{3} \cdot 9 \mathrm{H}_{2} \mathrm{O}$ and TEOS), AlO-NC (with the addition of $\left.\mathrm{Al}\left(\mathrm{NO}_{3}\right)_{3} \cdot 9 \mathrm{H}_{2} \mathrm{O}\right)$, $\mathrm{SiO}-\mathrm{NC}$ (with the addition of TEOS), and SiAlO-NC (with the addition of both $\mathrm{Al}\left(\mathrm{NO}_{3}\right)_{3} \cdot 9 \mathrm{H}_{2} \mathrm{O}$ and TEOS), respectively.

\subsection{Characterization}

The microstructures were observed by an emission scanning electron microscope (SEM, Hitachi S-4800) and a transmission electron microscope (TEM, JEOL 2100F). Raman spectra were collected on a thermal dispersive spectrometer $(\lambda=532 \mathrm{~nm}, 10 \mathrm{~mW})$. X-ray diffraction (XRD) was performed on a Bruker D8 Advanced diffractometer with $\mathrm{Cu}-\mathrm{K} \alpha$ irradiation $(\lambda=0.15406 \mathrm{~nm}, 2 \theta=$ $\left.10^{\circ}-80^{\circ}\right)$. Specific surface areas and pore size distributions were obtained by nitrogen adsorption measure- ments, performed with ASAP 2020M (Micromeritics). X-ray photoelectron spectroscopy (XPS, Thermo VG Scientific) was carried out under vacuum using Al-K $\alpha$ irradiation $(1486.6 \mathrm{eV})$ generated at $400 \mathrm{~W}$ and $15 \mathrm{kV}$.

\section{Results and discussion}

Variable-structure carbon materials were prepared by tuning the compositions of precursors, as shown in Fig. 1. Firstly, self-assembly process of Pluronic P123 takes place $^{[11]}$. Then, TEOS gradually hydrolyzes to form $\mathrm{Si}-\mathrm{O}-\mathrm{Si}$ network. In the sintering process, $\mathrm{Al}\left(\mathrm{NO}_{3}\right)_{3} \cdot 9 \mathrm{H}_{2} \mathrm{O}$ is dehydrated into aluminum oxide, and Al-N bonding forms in the $\mathrm{NH}_{3}$ atmosphere. Meanwhile, $\mathrm{Si}-\mathrm{O}-\mathrm{Si}$ network interacts with $\mathrm{Al}-\mathrm{N}$ bonding. On one hand, the interaction between $\mathrm{Si}-\mathrm{O}-\mathrm{Si}$ network and $\mathrm{Al}-\mathrm{N}$ bonding introduces more defects and promotes $\mathrm{O}$ in oxides bond with $\mathrm{N}$ in carbon materials during the reaction, which makes it difficult to escape, achieving high nitrogen content. On the other hand, this empowers carbon materials with high pore volume and broad pore size distribution. The detailed discussion is provided below.

The addition of $\mathrm{Al}\left(\mathrm{NO}_{3}\right)_{3} \cdot 9 \mathrm{H}_{2} \mathrm{O}$ and TEOS affects the morphology and structures of as-prepared carbon materials. First, the morphology of these carbon materials varies by adjusting the precursor composition, which is coral-like for $\mathrm{NC}$, sphere-like for $\mathrm{AlO}-\mathrm{NC}$ and 3D for $\mathrm{SiO}-\mathrm{NC}$ and $\mathrm{SiAlO}-\mathrm{NC}$ in Fig. 2(a-d). The coral-like morphology for $\mathrm{NC}$ is attributed to the co-assembling between pyrrole and the surfactant template ${ }^{[11]}$. NC shows microporous structure in Fig. 2(e). After adding $\mathrm{Al}\left(\mathrm{NO}_{3}\right)_{3} \cdot 9 \mathrm{H}_{2} \mathrm{O}$ and lowering solution $\mathrm{pH}$, self-assembling process of $\mathrm{P} 123$ is influenced. Therefore, pyrrole monomer polymerizes to sphere-like polypyrrole precursor, independently ${ }^{[12]}$. Then, after chemical vapor deposition

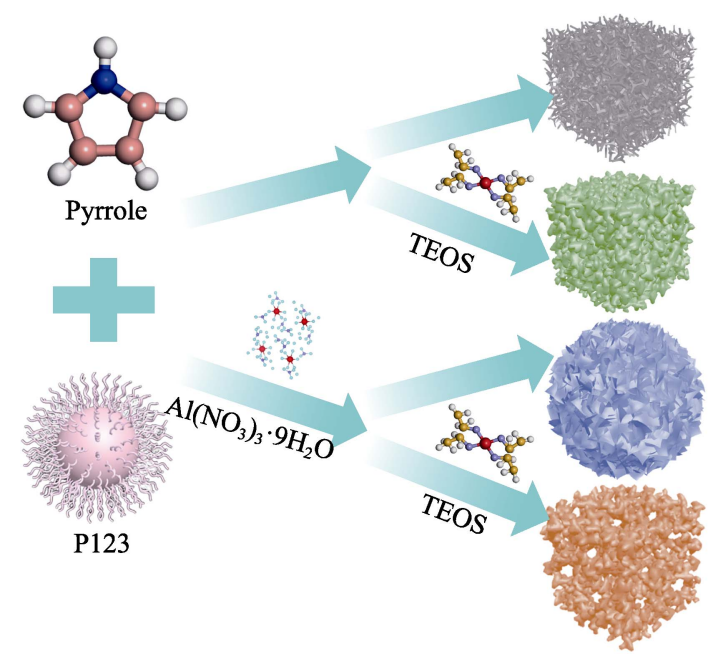

Fig. 1 Schematic processing route from precursors to variable-structure carbon materials 

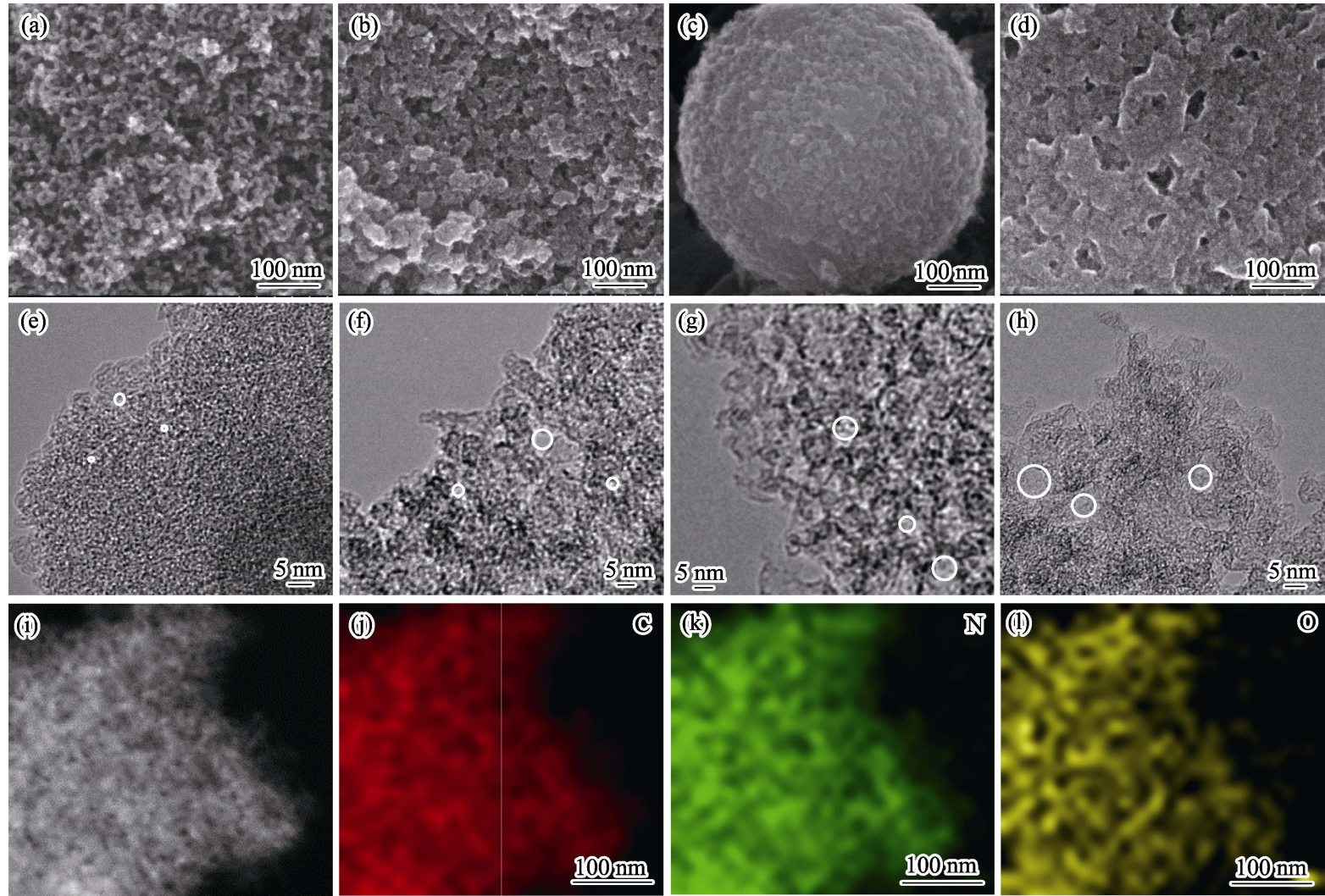
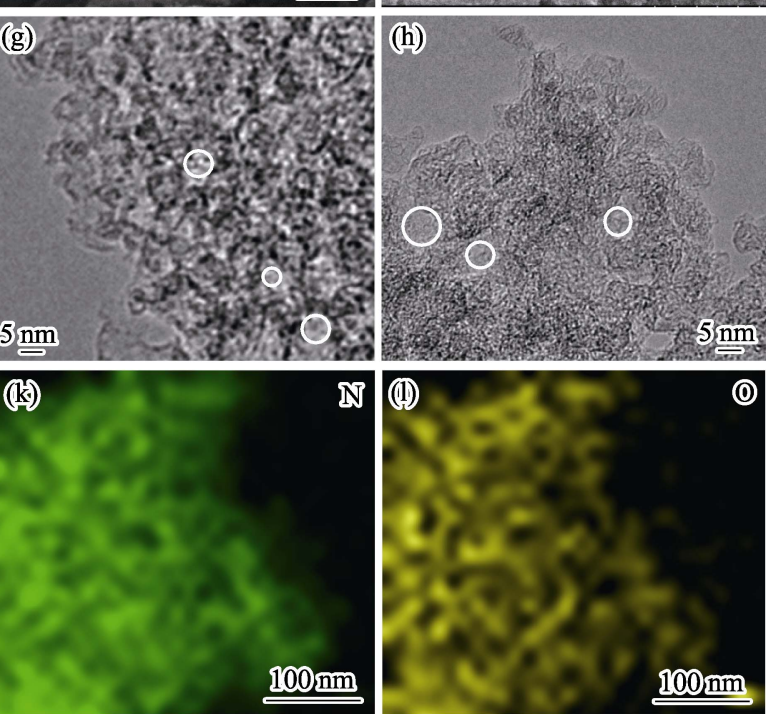

Fig. 2 (a-d) SEM and (e-h) HRTEM images of (a, e) NC, (b, f) SiO-NC, (c, g) AlO-NC and $(\mathrm{d}, \mathrm{h}) \mathrm{SiAlO}-\mathrm{NC}$, and (i-l) energy dispersive spectroscopy (EDS) elemental mappings of SiAlO-NC

(CVD), the sphere-like carbon material, AlO-NC, with abundant mesopores is prepared in Fig. 2(f). The 3D skeletons of $\mathrm{SiO}-\mathrm{NC}$ and $\mathrm{SiAlO}-\mathrm{NC}$ are formed by Si-O-Si network and P123, separated by many disordered mesopores ${ }^{[13]}$. These structures are in accordance with what are observed in high-resolution TEM (HRTEM) (Fig. 2(g-h)). The corresponding elemental mappings of SiAlO-NC confirm homogeneous distributions of $\mathrm{C}, \mathrm{N}$ and $\mathrm{O}$ elements in SiAlO-NC, as shown in Fig. 2(i-1).

Moreover, these carbon materials have diverse pore size distributions. With the interaction of oxides, the pore structure becomes richer. This phenomenon is demonstrated by the nitrogen adsorption-desorption isotherms (Fig. 3(a)) and pore size distributions (Fig. 3(b)). SiAlO-NC possesses the richest pore structure that distributes from 0.5 to $60 \mathrm{~nm}$. As listed in Table 1, SiAlO-NC has large surface area $\left(703.20 \mathrm{~m}^{2} \cdot \mathrm{g}^{-1}\right)$ and total pore volume $\left(1.78 \mathrm{~cm}^{3} \cdot \mathrm{g}^{-1}\right)$ resulting from the interaction between the $\mathrm{Si}-\mathrm{O}-\mathrm{Si}$ network and $\mathrm{Al}\left(\mathrm{NO}_{3}\right)_{3} \cdot 9 \mathrm{H}_{2} \mathrm{O}$. Wide pore size distribution is beneficial for the rate capability of the material. However, all of the other materials display narrow distribution. In addition, Raman spectra reflect the difference (Fig. S1(a)). $I_{\mathrm{D}} / I_{\mathrm{G}}$ is 1.00 for $\mathrm{NC}, 1.01$ for $\mathrm{SiO}-\mathrm{NC}, 1.03$ for $\mathrm{AlO}-\mathrm{NC}$ and 1.02 for SiAlO-NC. The D band at $\sim 1340 \mathrm{~cm}^{-1}$ is commonly ascribed to the defects and edges of graphene-like carbon materials, and the intensity ratio of $D$ band to $G$ band $\left(\sim 1570 \mathrm{~cm}^{-1}\right)$ typically suggests the defect degree of carbon materials ${ }^{[14]}$.

Furthermore, the presence of oxides also increases the $\mathrm{N}$ contents of carbon materials even at high temperature $\left(1000{ }^{\circ} \mathrm{C}\right)$ (Table 1). From XPS spectra, nitrogen content of SiAlO-NC is 5.29at\%, which is higher than those of NC (1.42at \%), SiO-NC (1.66at \%), and AlO-NC (3.52at \%).

The phenomenon is rarely reported for $\mathrm{N}$-doped carbon materials, tuning nitrogen content particularly at temperatures as high as $1000{ }^{\circ} \mathrm{C}$. For demonstrating the phenomenon, C1s and N1s XPS spectra of the carbon materials (Fig. 3(c-d) and Fig. S2) are deconvoluted. The C1s spectrum of SiAlO-NC is deconvoluted at 284.7, 285.3, 286.5, and $288.5 \mathrm{eV}$, corresponding to $\mathrm{sp}^{2} \mathrm{C}$, N-bonded $\mathrm{sp}^{2} \mathrm{C}, \mathrm{N}$-bonded $\mathrm{sp}^{3} \mathrm{C}$ and $\mathrm{C}-\mathrm{O}$, respectively ${ }^{[15]}$. Its N1s band is deconvoluted at $398.5,400.0$, and $401.3 \mathrm{eV}$, corresponding to pyridinic nitrogen, pyrrolic nitrogen, and graphitic nitrogen, separately ${ }^{[16]}$. After etching, the atomic percentage of active nitrogen is $0.24 \%$ for $\mathrm{NC}, 0.58 \%$ for $\mathrm{SiO}-\mathrm{NC}, 2.53 \%$ for $\mathrm{AlO}-\mathrm{NC}$ and $3.70 \%$ for SiAlO-NC. SiAlO-NC owns the highest nitrogen and active nitrogen contents, which are attributed to the interaction between $\mathrm{Si}-\mathrm{O}-\mathrm{Si}$ network and aluminum oxide. This hypothesis can be demonstrated by the following analysis. 

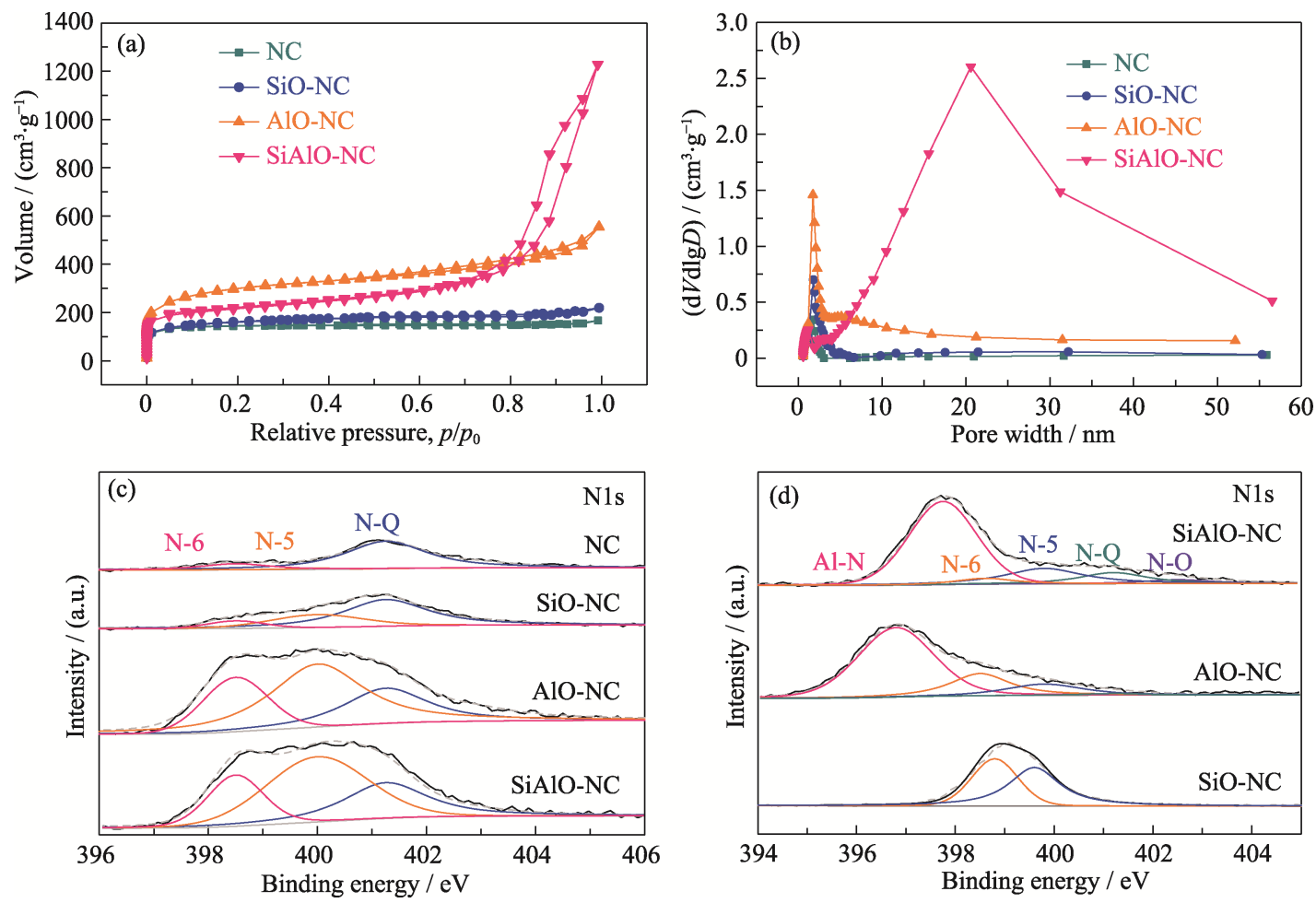

Fig. 3 (a) Nitrogen adsorption-desorption isotherms and (b) pore size distributions of NC, SiO-NC, AlO-NC, SiAlO-NC (after removing templates), N1s XPS spectra of (c) NC, SiO-NC, AlO-NC, SiAlO-NC (after removing templates) and

(d) $\mathrm{SiO}-\mathrm{NC}, \mathrm{AlO}-\mathrm{NC}, \mathrm{SiAlO}-\mathrm{NC}$ (without removing templates)

Table 1 BET and elemental parameters of samples

\begin{tabular}{cccccc}
\hline Sample & $\begin{array}{c}\mathrm{SSA} \\
/\left(\mathrm{m}^{2} \cdot \mathrm{g}^{-1}\right)\end{array}$ & $\begin{array}{c}\text { Pores } \\
\text { volume } \\
/\left(\mathrm{cm}^{3} \cdot \mathrm{g}^{-1}\right)\end{array}$ & $\begin{array}{c}\mathrm{N} \\
/ \mathrm{at} \%\end{array}$ & $\begin{array}{c}\mathrm{N}-6 \\
/ \mathrm{at} \%\end{array}$ & $\begin{array}{c}\mathrm{N}-5 \\
/ \mathrm{at} \%\end{array}$ \\
\hline $\mathrm{NC}$ & 440.78 & 0.07 & 1.42 & 0.21 & 0.03 \\
$\mathrm{SiO}-\mathrm{NC}$ & 520.78 & 0.19 & 1.66 & 0.14 & 0.44 \\
$\mathrm{AlO}-\mathrm{NC}$ & 980.35 & 0.68 & 3.52 & 0.78 & 1.75 \\
$\mathrm{SiAlO}-\mathrm{NC}$ & 703.20 & 1.78 & 5.29 & 1.17 & 2.53 \\
\hline
\end{tabular}

Firstly, previous studies suggest that the high surface area with more defects and edges in the carbon materials facilitates the formation of the high nitrogen and active nitrogen contents ${ }^{[17]}$. Therefore, considering that AlO-NC has more defects than $\mathrm{SiO}-\mathrm{NC}$ and $\mathrm{NC}$, the nitrogen content of AlO-NC should be higher than those of SiO-NC and NC, in accordance with the result of XPS spectra.

Although the specific surface area and defects of SiAlO-NC are less than those of AlO-NC, the nitrogen content of SiAlO-NC (5.29at\%) is higher than that of AlO-NC (3.52at\%). Thus, to further explore the mechanism, we deconvolute N1s band of SiO-NC, AlO-NC and SiAlO-NC without removing templates (Fig. 3(d)). The Al-N bonding forms in AlO-NC and SiAlO-NC. The peak position (binding energy) of the Al-N bonding in SiAlO-NC is higher than that in AlO-NC, suggesting the interaction between $\mathrm{Si}-\mathrm{O}-\mathrm{Si}$ network and $\mathrm{Al}-\mathrm{N}$. This interaction could promote the activity of oxygen atoms in oxides because SiAlO-NC owns relatively strong $\mathrm{N}-\mathrm{O}$ bonding in contrast with SiO-NC and AlO-NC. After etching, nearly no $\mathrm{N}-\mathrm{O}$ bonding exists in SiAlO-NC, $\mathrm{SiO}-\mathrm{NC}$ and $\mathrm{AlO}-\mathrm{NC}$, so that oxygen atoms in oxides bond with nitrogen atoms in carbon materials for $\mathrm{SiAlO}-\mathrm{NC}$ in the sintering process, making the nitrogen atoms difficult to escape.

Besides, the N1s bands of the carbon materials, which are prepared at 900 and $1100{ }^{\circ} \mathrm{C}$ for SiAlO-NC, are also deconvoluted, as shown in Fig. S3 and Table S1. Clearly, the interaction between $\mathrm{Si}-\mathrm{O}-\mathrm{Si}$ network and $\mathrm{Al}-\mathrm{N}$ bonding is independent of the sintering temperature for carbon materials, which suggests that this method is promising for tuning nitrogen species and content in carbon materials, achieving high active $\mathrm{N}$ content for electrochemical fields, such as supercapacitors and electrocatalysis.

To explore the importance of tuning $\mathrm{N}$ species and content in these carbon materials, three-electrode electrochemical cells are assembled in aqueous solution. Considering that the prepared carbon materials have the best electrochemical performances in $1.0 \mathrm{~mol} \cdot \mathrm{L}^{-1} \mathrm{H}_{2} \mathrm{SO}_{4}$, it is chosen as aqueous solution electrolyte. Cyclic voltammetry (CV) curves at $10 \mathrm{mV} \cdot \mathrm{s}^{-1}$ (Fig. 4(a)) are approximately rectangular, even at $100 \mathrm{mV} \cdot \mathrm{s}^{-1}$ (Fig. S4(a)). These results show that the prepared carbon materials own good capacitive behavior. For SiAlO-NC, two Faradaic 
peaks (one during charging, another during discharging) are almost symmetric and obvious in Fig. 4(a), owing to the high active $\mathrm{N}$ content. With the introduction of oxides, the capacitance is gradually improved due to higher specific surface area and active N content. Specifically, SiAlO-NC has the best performance at all current densities and achieves $302 \mathrm{~F} \cdot \mathrm{g}^{-1}$ at $1 \mathrm{~A} \cdot \mathrm{g}^{-1}$, which is higher than those of $\mathrm{NC}\left(160 \mathrm{~F} \cdot \mathrm{g}^{-1}\right), \mathrm{SiO}-\mathrm{NC}\left(180 \mathrm{~F} \cdot \mathrm{g}^{-1}\right)$ and AlO-NC (240 F. $\mathrm{g}^{-1}$ ) (Fig. 4(b) and Fig. S5). To find the optimal nitrogen-rich carbon material, we tried different heating temperatures, and SiAlO-NC at $1000{ }^{\circ} \mathrm{C}$ still shows the best performance (Fig. S6). SiAlO-NC achieves $218 \mathrm{~F} \cdot \mathrm{g}^{-1}$ at the current density of $20 \mathrm{~A} \cdot \mathrm{g}^{-1}$ and $177 \mathrm{~F} \cdot \mathrm{g}^{-1}$ at $120 \mathrm{~A} \cdot \mathrm{g}^{-1}$ (Fig. S4(b)). The cycling stability of SiAlO-NC is extraordinary at $20 \mathrm{mV} \cdot \mathrm{s}^{-1}$. After 20000 cycles, the capacitive retention is about $92 \%$ in $1 \mathrm{~mol} \cdot \mathrm{L}^{-1}$ $\mathrm{H}_{2} \mathrm{SO}_{4}$ (Fig. S7). The excellent capacitive performance origins from the high-temperature sintering process, leading to the interaction between $\mathrm{Si}-\mathrm{O}-\mathrm{Si}$ network and aluminum oxide, thereby empowering high electronic conductivity, active nitrogen content, hierarchical pore structure and 3D interconnected structure in SiAlO-NC.

We assembled two-electrode electrochemical cells, using symmetric SiAlO-NC electrodes, and tested at operating voltage $(1.2 \mathrm{~V})$ in aqueous solution $\left(1.0 \mathrm{~mol} \cdot \mathrm{L}^{-1}\right.$ $\mathrm{H}_{2} \mathrm{SO}_{4}$ ) for validating electrochemical performance. $\mathrm{CV}$ curves at $10 \mathrm{mV} \cdot \mathrm{s}^{-1}$ are nearly rectangular (Fig. 4(c)), even at $100 \mathrm{mV} \cdot \mathrm{s}^{-1}$ (Fig. S8). GCD curves (Fig. S9(a)), even at $40 \mathrm{~A} \cdot \mathrm{g}^{-1}$ (Fig. S9(b)), are almost linear and symmetrical. All these results reflect the purely capacitive behavior of SiAlO-NC. Ragone plots for SiAlO-NC and other reported nitrogen-carbon materials are shown in Fig. 4(d). At $300 \mathrm{~W} \cdot \mathrm{kg}^{-1}$, the energy density of SiAlO-NC is calculated to be $13.41 \mathrm{Wh} \cdot \mathrm{kg}^{-1}$, which is higher than those of most reported nitrogen-carbon materials ${ }^{[18-23]}$, indicating that it is a comparable electrode material for supercapacitors (Table S2).

\section{Conclusions}

In summary, we successfully tuned nitrogen species and content by the interaction between $\mathrm{Si}-\mathrm{O}-\mathrm{Si}$ network and aluminum oxide. Different morphology designs also affect the defect concentration, specific surface area, pore size distribution and pore volume. This interaction between $\mathrm{Si}-\mathrm{O}-\mathrm{Si}$ network and Al-N affects the activities of oxygen atoms in oxides, which provides oxygeninduced nitrogen fixation. As-prepared N-rich carbon material is endowed with high nitrogen doping level of $5.29 \mathrm{at} \%$, high pore volume of $1.78 \mathrm{~cm}^{3} \cdot \mathrm{g}^{-1}$, hierarchical pore structure of $0.5-60 \mathrm{~nm}$, and $3 \mathrm{D}$ interconnected structure. Therefore, these synergetic effects give rise to high capacitance of $302 \mathrm{~F} \cdot \mathrm{g}^{-1}$, excellent rate capability of $177 \mathrm{~F} \cdot \mathrm{g}^{-1}$ at $120 \mathrm{~A} \cdot \mathrm{g}^{-1}$ and good durability $(92 \%$ after
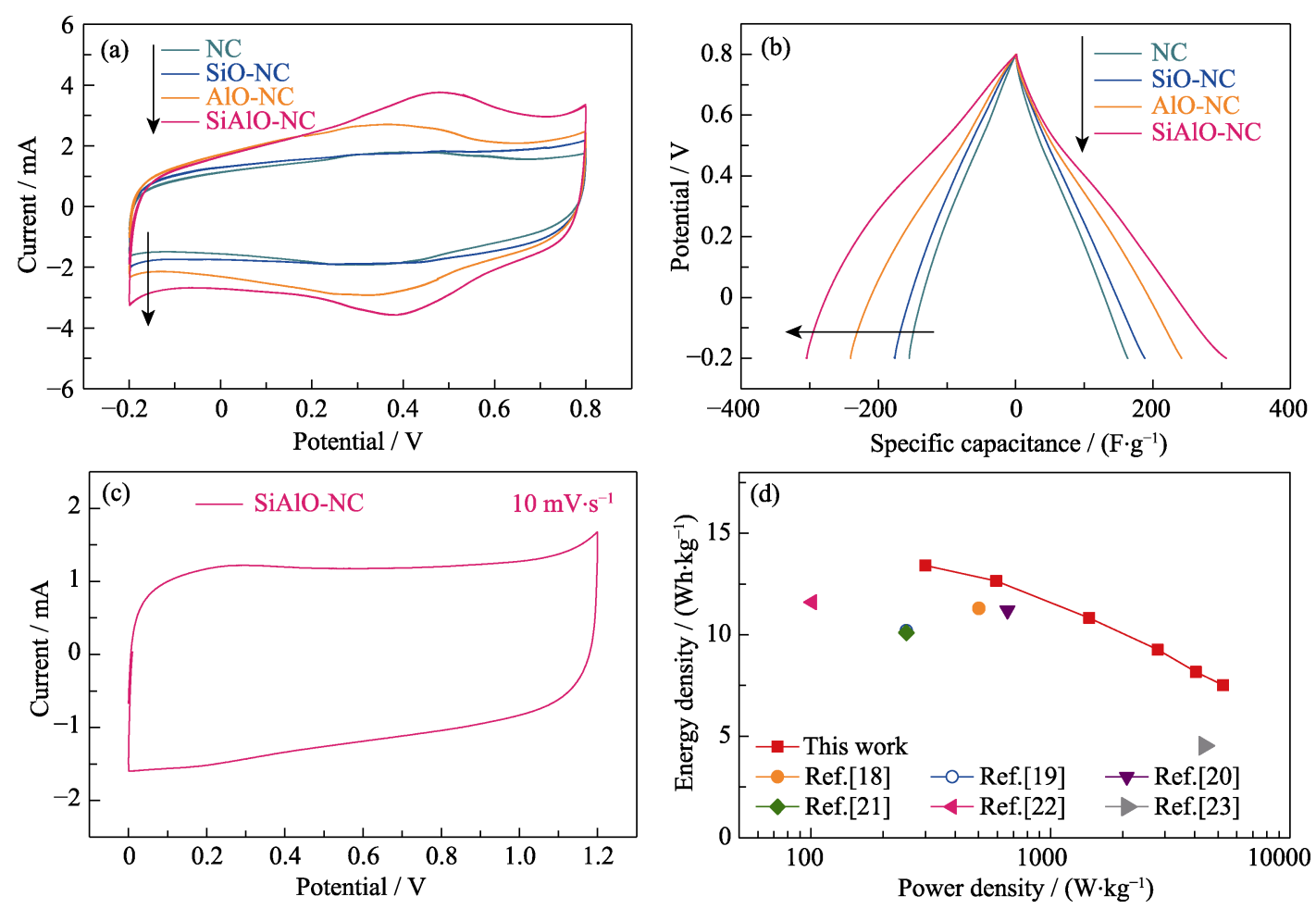

Fig. 4 (a) CV curves at $10 \mathrm{mV} \cdot \mathrm{s}^{-1}$ and (b) galvanostatic charge/discharge (GCD) curves of NC, SiO-NC, AlO-NC, SiAlO-NC at $1 \mathrm{~A} \cdot \mathrm{g}^{-1}$ in three-electrode configuration; (c) $\mathrm{CV}$ curve of symmetric cell with SiAlO-NC, and

(d) Ragone plots for SiAlO-NC and other nitrogen-carbon materials 
20000 cycles). This strategy to tune nitrogen species and content in carbon materials at high temperature is a promising method to prepare high performance N-rich carbon materials.

\section{Supporting materials}

Supporting materials related to this article can be found at https://doi.org/10.15541/jim20200498.

\section{References:}

[1] ZHANG L L, ZHAO X S. Carbon-based materials as supercapacitor electrodes. Chemical Society Reviews, 2009, 38: 2520-2531.

[2] HAO Y X, QIAN M, XU J J, et al. Porous cotton-derived carbon: synthesis, microstructure and supercapacitive performance. Journal of Inorganic Materials, 2018, 33(1): 93-99.

[3] YU J H, XU L L, ZHU Q Q, et al. Superior electrochemical performance of graphene via carboxyl functionalization and surfactant intercalation. Journal of Inorganic Materials, 2016, 31(2): 220-224.

[4] HWANG J Y, LI M P, EI-KADY M F, et al. Next-generation activated carbon supercapacitors: a simple step in electrode processing leads to remarkable gains in energy density. Advanced Functional Materials, 2017, 27: 1605745.

[5] ZHOU Y, JIA Z X, SHI L L, et al. Pressure difference-induced synthesis of P-doped carbon nanobowls for high-performance supercapacitors. Chemical Engineering Journal, 2020, 385: 123858.

[6] SEREDYCH M, HULICOVA-JURCAKOVA D, LU G Q, et al. Surface functional groups of carbons and the effects of their chemical character, density and accessibility to ions on electrochemical performance. Carbon, 2008, 46: 1475-1488.

[7] HAN S W, BANG J, KO S H, et al. Variation of nitrogen species in zeolite-templated carbon by low-temperature carbonization of pyrrole and the effect on oxygen reduction activity. Journal of Materials Chemistry A, 2019, 7: 8353-8360.

[8] LI S Y, GU Q Q, CAO N, et al. Defect enriched N-doped carbon nanoflakes as robust carbocatalysts for $\mathrm{H}_{2} \mathrm{~S}$ selective oxidation. Journal of Materials Chemistry A, 2020, 8: 8892-8902.

[9] CHOI C H, PARK S H, WOO S I. Binary and ternary doping of nitrogen, boron, and phosphorus into carbon for enhancing electrochemical oxygen reduction activity. ACS Nano, 2012, 6(8): 7084-7091.

[10] HE H, HUANG D, TANG Y G, et al. Tuning nitrogen species in three-dimensional porous carbon via phosphorus doping for ultra-fast potassium storage. Nano Energy, 2019, 57: 728-736.
[11] TO J W F, HE J J, MEI J G, et al. Hierarchical N-doped carbon as $\mathrm{CO}_{2}$ adsorbent with high $\mathrm{CO}_{2}$ selectivity from rationally designed polypyrrole precursor. Journal of The American Chemical Society, 2016, 138(3): 1001-1009.

[12] SU F B, TIAN Z Q, POH C K, et al. Pt nanoparticles supported on nitrogen-doped porous carbon nanospheres as an electrocatalyst for fuel cells. Chemistry of Materials, 2010, 22: 832-839.

[13] LIU R L, SHI Y F, WAN Y, et al. Triconstituent co-assembly to ordered mesostructured polymer-silica and carbon-silica nanocomposites and large-pore mesoporous carbons with high surface areas. Journal of The American Chemical Society, 2006, 128: 11652-11662.

[14] FERRARI A C, ROBERTSON J. Interpretation of Raman spectra of disordered and amorphous carbon. Physical Review B, 2000, 61(20): 14095-14107.

[15] XU F, SUN P, QIAN M, et al. Variable texture few-layer ordered macroporous carbon for high-performance electrochemical capacitors. Journal of Materials Chemistry A, 2017, 5: 25171-25176.

[16] WANG H B, MAIYALAGAN T, WANG X. Review on recent progress in nitrogen-doped graphene: synthesis, characterization, and its potential applications. ACS Catalysis, 2012, 2(5): 781-794.

[17] SUN J, WANG L, SONG R, et al. Enhancing pyridinic nitrogen level in graphene to promote electrocatalytic activity for oxygen reduction reaction. Nanotechnology, 2016, 27: 055404.

[18] SUN H, QUAN H Y, PAN M H, et al. Nitrogen-doped hierarchically structured porous carbon as a bifunctional electrode material for oxygen reduction and supercapacitor. Journal of Alloys and Compounds, 2020, 826: 154208 .

[19] DEKA N, BARMAN J, KASTHURI S, et al. Transforming waste polystyrene foam into $\mathrm{N}$-doped porous carbon for capacitive energy storage and deionization applications. Applied Surface Science, 2020, 511: 145576.

[20] DU J, CHEN A B, LIU L, et al. N-doped hollow mesoporous carbon spheres prepared by polybenzoxazines precursor for energy storage. Carbon, 2020, 160: 265-272.

[21] WANG Y Z, LIU Y X, WANG D H, et al. Free-standing honeycomb-like $\mathrm{N}$ doped carbon foam derived from coal tar pitch for high-performance supercapacitor. Applied Surface Science, 2020, 506: 145014

[22] HUO S L, ZHANG X L, LIANG B L, et al. Synthesis of interconnected hierarchically porous carbon networks with excellent diffusion ability based on $\mathrm{NaNO}_{3}$ crystal-assisted strategy for high performance supercapacitors. Journal of Power Sources, 2020, 450: 227612.

[23] YUKSEL R, BUYUKCAKIR O, PANDA P K, et al. Necklace-like nitrogen doped tubular carbon 3D frameworks for electrochemical energy storage. Advanced Functional Materials, 2020, 30(10): 1909725. 


\title{
基于结构调节碳材料的掺氮种类和含量及其 超级电容器储能应用
}

\author{
孙 鹏 ${ }^{1,2}$, 张绍宁 ${ }^{1,3}$, 毕 辉 ${ }^{1}$, 董武杰 ${ }^{1}$, 黄富强 ${ }^{1,3,4}$
}

(1. 中国科学院 上海硅酸盐研究所, 高性能陶瓷和超微结构国家重点实验室, 上海 200050; 2 . 中国科学院大学 材料科学与光电技术学院, 北京 $100049 ; 3$. 上海科技大学 物理科学与技术学院, 上海 $200031 ; 4$. 北京大学 化学 与分子工程学院, 稀土材料化学及应用国家重点实验室, 北京 100871)

摘 要: 碳材料是极具潜力的超级电容器电极材料, 但是其容量较低。异质原子掺杂, 尤其是氮掺杂, 是大幅度提高 碳材料电化学性能的有效方法。但是在碳材料中实现高含量的活性氮掺杂仍极具挑战。本研究通过 $\mathrm{Si}-\mathrm{O}-\mathrm{Si}$ 网络和氧 化铝之间的相互作用成功调节碳材料的掺氮种类及其含量。除此之外, 通过调节前驱体组成, 碳材料的结构可以从珊 瑚状转变为三维结构。在反应中, 氧化物中的氧原子可以和碳材料中氮原子成键, 氮原子不易逃离, 从而实现高含量 氮掺杂 $\left(5.29 \mathrm{at} \% @ 1000{ }^{\circ} \mathrm{C}\right)$ 。另一方面, 相互作用使碳材料孔体积增大 $\left(1.78 \mathrm{~m}^{3} \cdot \mathrm{g}^{-1}\right)$ 和孔径分布加宽 $(0.5 \sim 60 \mathrm{~nm})$ 。因此, 获得的富氮掺杂碳材料具有 $302 \mathrm{~F} \cdot \mathrm{g}^{-1} @ 1 \mathrm{~A} \cdot \mathrm{g}^{-1}$ 的高容量和 $177 \mathrm{~F} \cdot \mathrm{g}^{-1} @ 120 \mathrm{~A} \cdot \mathrm{g}^{-1}$ 的杰出倍率性能。此独特的固氮方 法是一种有潜力的制备高性能超级电容器电极材料的策略。

关 键 词: 碳材料; 氮原子固定; 相互作用; 形貌设计; 超级电容器 中图分类号: 0782 文献标志码: A 
Supporting materials:

\title{
Tuning Nitrogen Species and Content in Carbon Materials through Constructing Variable Structures for Supercapacitors
}

\author{
SUN Peng ${ }^{1,2}$, ZHANG Shaoning ${ }^{1,3}$, BI Hui ${ }^{1}$, DONG Wujie ${ }^{1}$, HUANG Fuqiang ${ }^{1,3,4}$
}

(1. State Key Laboratory of High Performance Ceramics and Superfine Microstructure, Shanghai Institute of Ceramics, Chinese Academy of Sciences, Shanghai 200050, China; 2. Center of Materials Science and Optoelectronics Engineering, University of Chinese Academy of Sciences, Beijing 100049, China; 3. School of Physical Science and Technology, ShanghaiTech University, Shanghai 200031, China; 4. State Key Laboratory of Rare Earth Materials Chemistry and Applications, College of Chemistry and Molecular Engineering, Peking University, Beijing 100871, China)

\section{Electrochemical characterization}

To fabricate supercapacitor electrodes, $20 \mathrm{mg}$ of the active material and $10 \mathrm{mg}$ of poly(vinylidene fluoride) PVDF were mixed in $2 \mathrm{~mL}$ of $\mathrm{N}$-methyl-2-pyrrolidone. Then $100 \mu \mathrm{L}$ slurry was coated onto a graphene foam, which was used as the collector. The electrode had exposed surface area of $1 \mathrm{~cm} \times 1 \mathrm{~cm}$ and was dried at $120{ }^{\circ} \mathrm{C}$ under vacuum. Electrochemical tests were performed on a CHI 760E electrochemical workstation (Shanghai Chenhua).

\section{Results and discussion}

There are some similarities among as-prepared carbon materials. In Raman spectra (Fig. S1(a)), there is a weak signal of 2D in all carbon materials, which suggests that they are composed of crystalline carbon, identical with the observation in XRD (Fig. S1(b)). Two broad peaks in all samples at about $24.0^{\circ}$ and $43.5^{\circ}$ correspond to the (002) and (101) crystal planes of the graphite structure. However, the broad peaks at about $24.0^{\circ}$ are slightly shifted to the left compared to graphite, which suggests that the interlayer distance, $d$-spacing, increases through this method.

Resistances of devices can be evaluated by electrochemical impedance spectroscopy (EIS) (Fig. S10), which is presented in Nyquist plots, fitting with the equivalent Randles circuit. According to the Nyquist plots, $R_{\mathrm{b}}$ (Ohmic resistance) is $1.62 \Omega$ for NC, $1.56 \Omega$ for SiO-NC, $1.59 \Omega$ for AlO-NC and $1.44 \Omega$ for SiAlO-NC, suggesting the resistance for SiAlO-NC is the lowest. This low resistance probably results from the wetting of materials improved by nitrogen doping, which lowers the interface resistance. $R_{\mathrm{ct}}$ (charge-transfer resistance) is $0.44 \Omega$ for NC and $0.40 \Omega$ for SiAlO-NC, which suggests that the charge-transfer kinetic improves with the interaction between $\mathrm{Si}-\mathrm{O}-\mathrm{Si}$ network and aluminum oxide. The absence of a semicircle at high frequencies for all four kinds of materials likely signifies fast ion diffusion in the electrodes. The impedance plots for NC, $\mathrm{SiO}-\mathrm{NC}, \mathrm{AlO}-\mathrm{NC}$ and SiAlO-NC are all parallel to
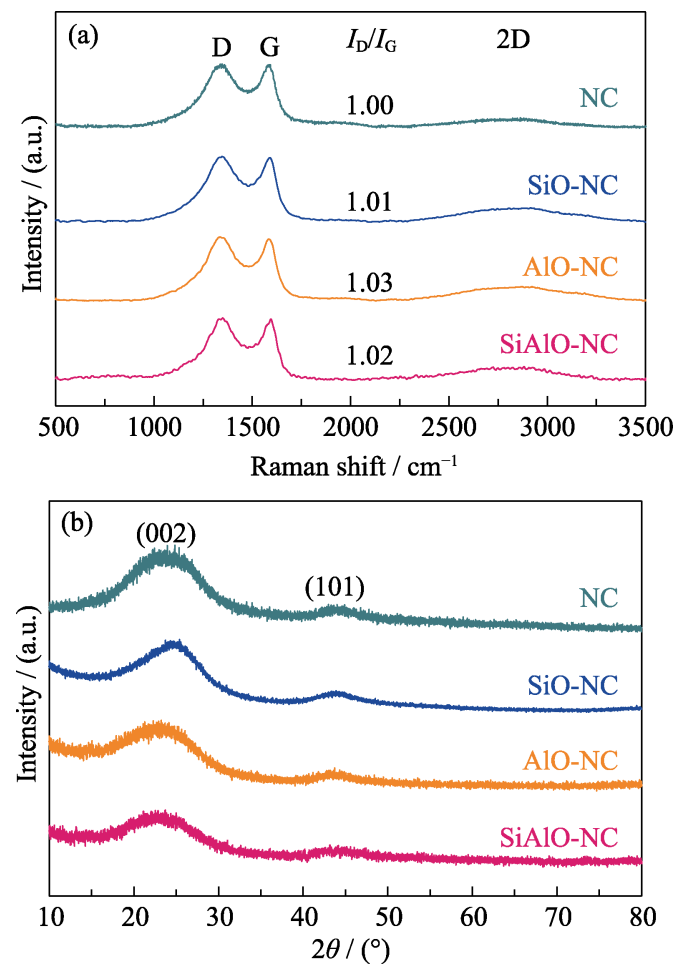

Fig. S1 (a) Raman spectra and (b) XRD patterns of NC, $\mathrm{SiO}-\mathrm{NC}, \mathrm{AlO}-\mathrm{NC}$ and $\mathrm{SiAlO}-\mathrm{NC}$

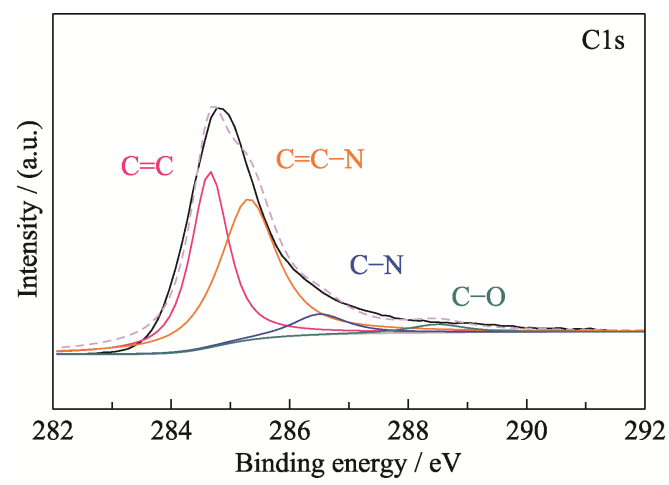

Fig. S2 C1s XPS spectrum of SiAlO-NC 

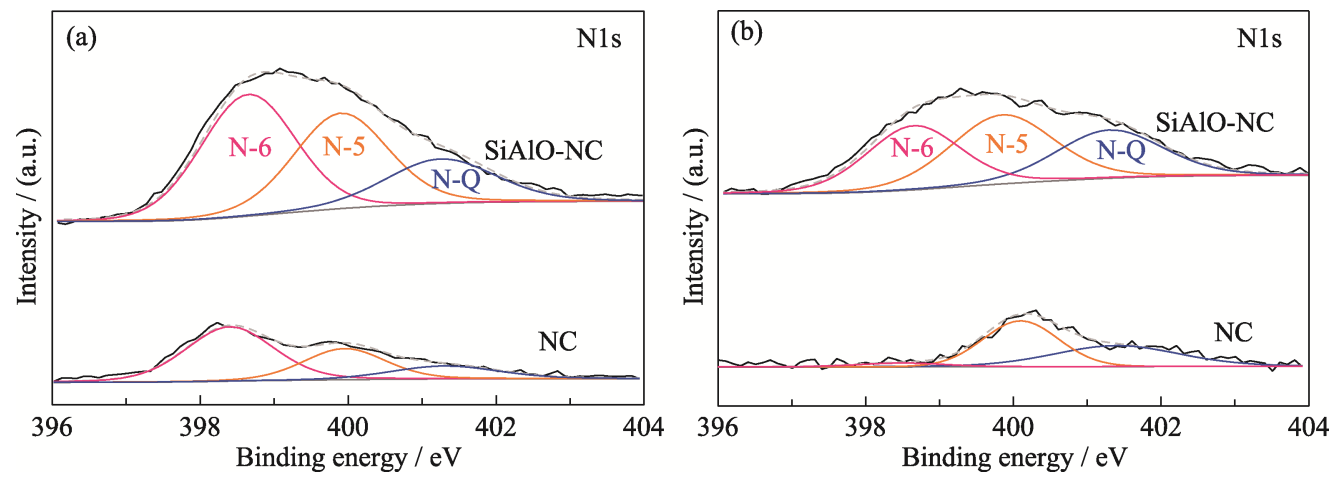

Fig. S3 N1s XPS spectra of NC and SiAlO-NC at (a) 900 and (b) $1100{ }^{\circ} \mathrm{C}$
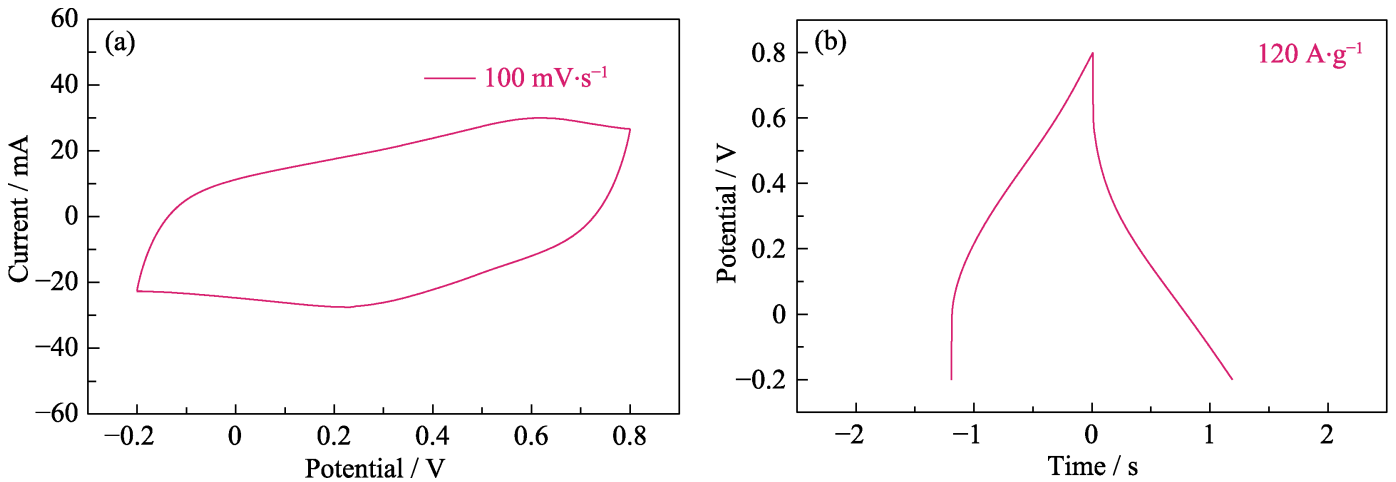

Fig. S4 (a) CV curve at $100 \mathrm{mV} \cdot \mathrm{s}^{-1}$ and (b) GCD curve at $120 \mathrm{~A} \cdot \mathrm{g}^{-1}$ of SiAlO-NC in three-electrode configuration

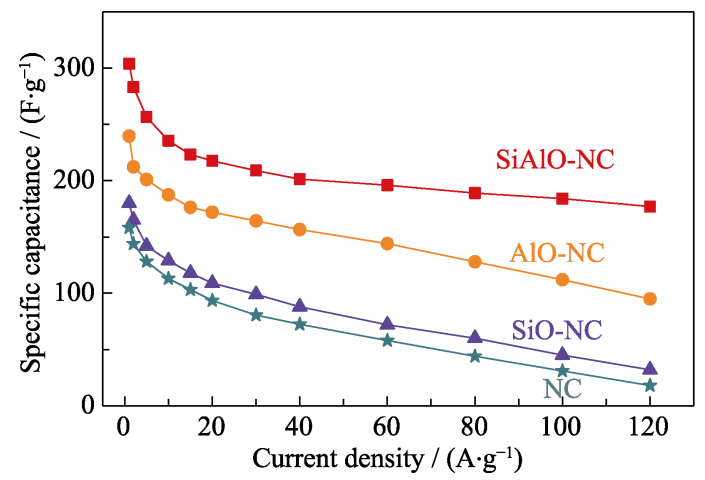

Fig. S5 Specific capacitances calculated from GCD curves $v s$. current density for NC, SiO-NC, AlO-NC and SiAlO-NC

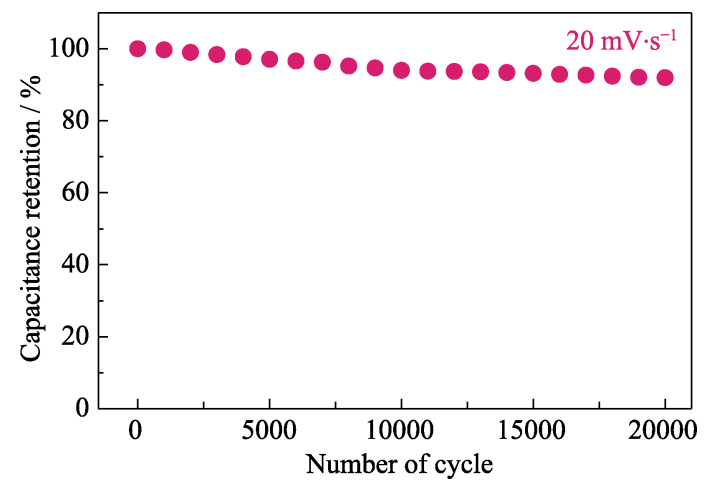

Fig. S7 Cycling performance of SiAlO-NC electrode measured in three-electrode configuration

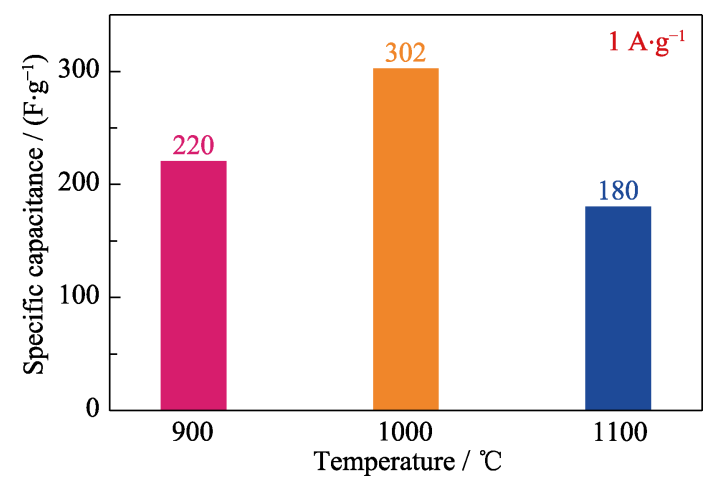

Fig. S6 Histograms of specific capacitance for SiAlO-NC at $1 \mathrm{~A} \cdot \mathrm{g}^{-1} v \mathrm{~s}$. the heating temperature

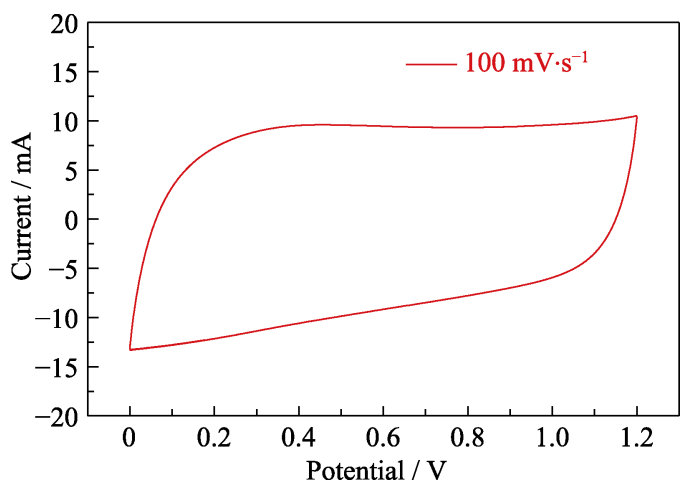

Fig. S8 CV curve of SiAlO-NC electrode measured in symmetric electrochemical cell at $100 \mathrm{mV} \cdot \mathrm{s}^{-1}$ 

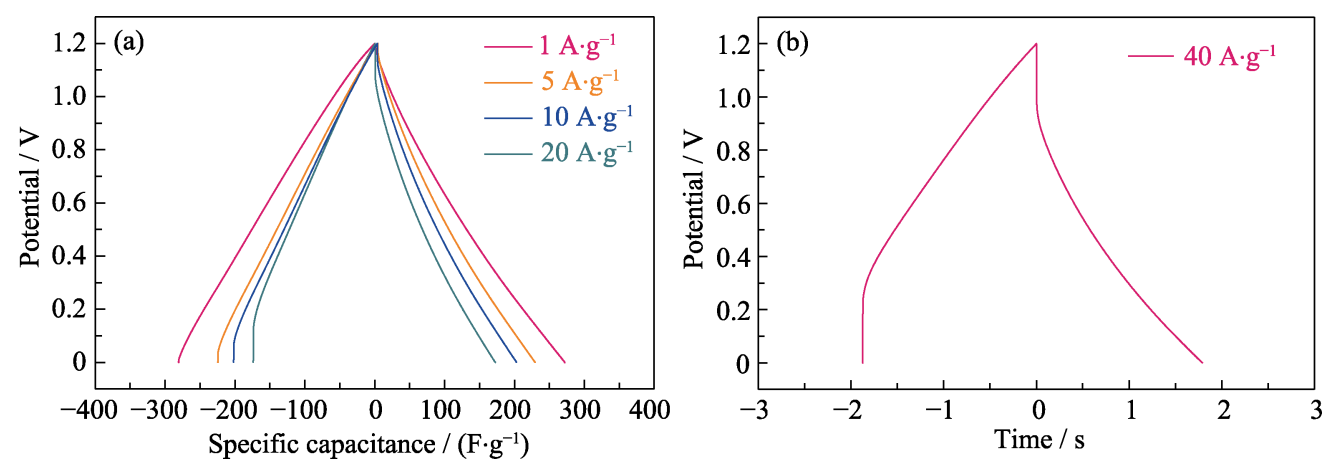

Fig. S9 GCD curves of SiAlO-NC electrode measured in symmetric electrochemical cells at (a) different current densities and (b) $40 \mathrm{~A} \cdot \mathrm{g}^{-1}$

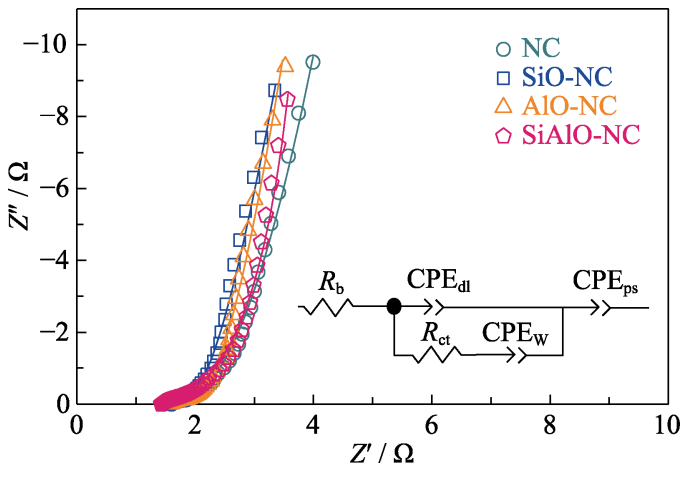

Fig. S10 Nyquist plots over 0.01 to $10^{5} \mathrm{~Hz}$ of NC, SiO-NC, $\mathrm{AlO}-\mathrm{NC}$ and $\mathrm{SiAlO}-\mathrm{NC}$ based on the fittings using equivalent Randles circuit model(inset) in three-electrode configuration

vertical lines at low frequencies, indicating the pure capacitive behavior.
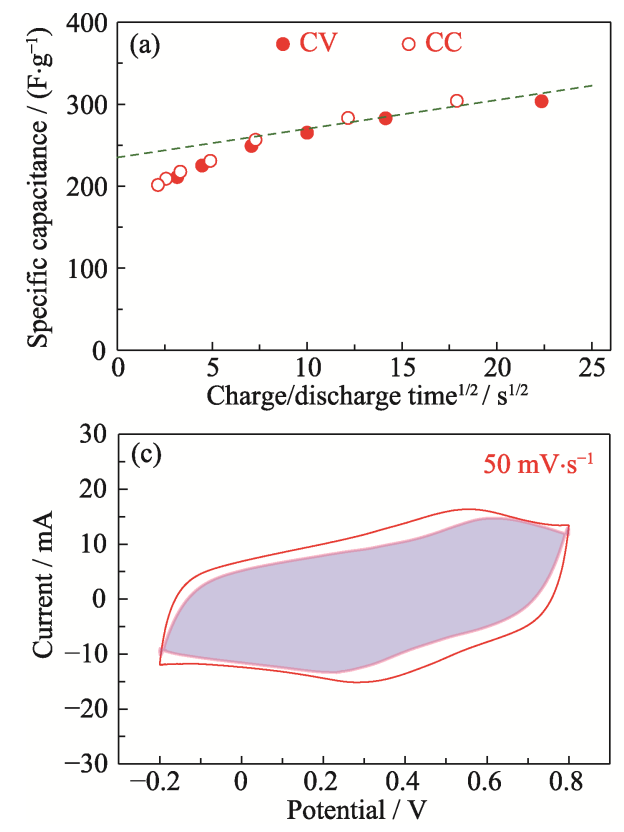

\section{Electrochemical analysis}

To further explore components of the capacitance in SiAlO-NC, the total capacitance is divided into two parts, which are rate-independent (such as EDLC) and diffusionlimited component (such as intercalation), according to the equation ${ }^{[1]}$ :

$$
C=k_{1}+k_{2} v^{-1 / 2}
$$

Here, on the right-hand side, $k_{2} v^{-1 / 2}$ is the diffusionlimited component. The potential scan rate, $v$, is inversely proportional to the half-cycle time $(T)$ in $\mathrm{CV}$ and $\mathrm{CC}$ tests. In $\mathrm{CV}$ test, $T$ is the time required to sweep over the voltage window. In the $\mathrm{CC}$ test, it is the time required to discharge. The rate-independent part, $k_{1}$, dominates in SiAlO-NC at about $235 \mathrm{~F} \cdot \mathrm{g}^{-1}$, from Fig. S11(a). The high $k_{1}$ suggests that SiAlO-NC owns good rate capability
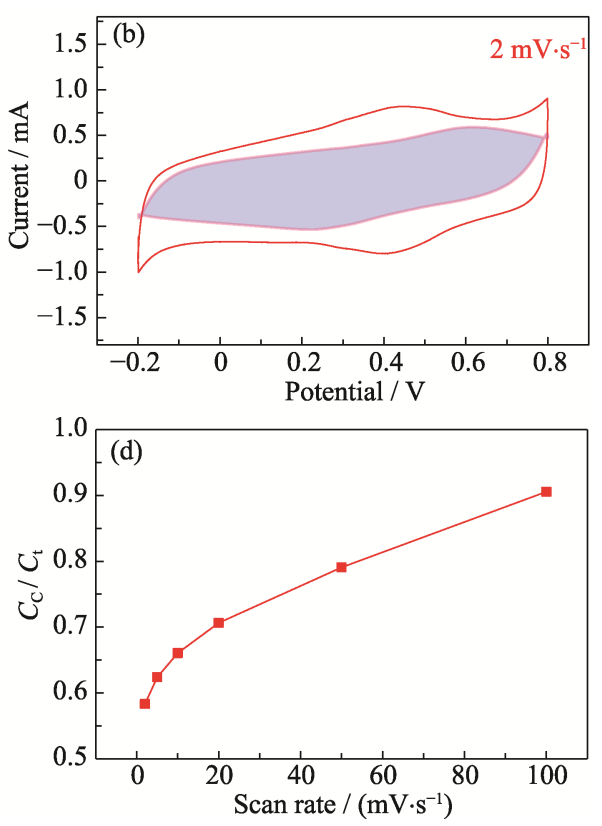

Fig. S11 Electrochemical performance of the SiAlO-NC sample

(a) Capacitance versus discharge time, $t^{1 / 2}$. Hollow symbols: $\mathrm{CC}$ test data, solid symbols: $\mathrm{CV}$ test data from 2 to $100 \mathrm{mV} \cdot \mathrm{s}^{-1}$; Extrapolation of capacitance to $t=0$ gives a rate-independent capacitance; Instantaneous current of the SiAlO-NC sample at (b) 2 and (c) $50 \mathrm{mV} \cdot \mathrm{s}^{-1}$, giving the shaded loop is the capacitive capacitance, and the region outside is the pseudocapacitance;

(d) Fraction of capacitive capacitance $C_{\mathrm{c}}$ in total capacitance $C_{\mathrm{t}}$ 
Table S1 Characteristic summary of NC and SiAlO-NC

\begin{tabular}{|c|c|c|c|c|c|c|c|c|c|}
\hline Sample & $\mathrm{N} / \mathrm{at} \%$ & N-6/at $\%$ & N-5/at $\%$ & $\mathrm{~N}-\mathrm{Q} / \mathrm{at} \%$ & Sample & $\mathrm{N} / \mathrm{at} \%$ & N-6/at\% & $\mathrm{N}-5 / \mathrm{at} \%$ & $\mathrm{~N}-\mathrm{Q} / \mathrm{at} \%$ \\
\hline $\mathrm{NC}\left(900{ }^{\circ} \mathrm{C}\right)$ & 2.81 & 1.54 & 0.82 & 0.45 & $\mathrm{NC}\left(1100{ }^{\circ} \mathrm{C}\right)$ & 0.61 & 0.03 & 0.32 & 0.26 \\
\hline SiAlO-NC $\left(900{ }^{\circ} \mathrm{C}\right)$ & 8.27 & 3.65 & 3.00 & 1.62 & SiAlO-NC $\left(1100{ }^{\circ} \mathrm{C}\right)$ & 4.33 & 1.61 & 1.27 & 1.45 \\
\hline
\end{tabular}

Table S2 Comparison of the specific capacitances, rate capabilities and cycling performances for previously reported $\mathrm{N}$-doped porous carbon materials

\begin{tabular}{|c|c|c|c|c|}
\hline Carbon material & $\begin{array}{l}\text { Specific capacitance } \\
\qquad /\left(\mathrm{F} \cdot \mathrm{g}^{-1}\right)\end{array}$ & $\begin{array}{l}\text { Rate capability } \\
\qquad /\left(\mathrm{F} \cdot \mathrm{g}^{-1}\right)\end{array}$ & Cycling performance & Ref. \\
\hline N-doped porous carbon & 327 at $1 \mathrm{~A} \cdot \mathrm{g}^{-1}$ & 200 at $20 \mathrm{~A} \cdot \mathrm{g}^{-1}$ & 10000 cycles@100\% & {$[2]$} \\
\hline N/S co-doped porous carbon & 272 at $1 \mathrm{~A} \cdot \mathrm{g}^{-1}$ & 172 at $100 \mathrm{~A} \cdot \mathrm{g}^{-1}$ & 5000 cycles at $5 \mathrm{~A} \cdot \mathrm{g}^{-1} @ 97.1 \%$ & {$[3]$} \\
\hline N/O co-doped carbon & 242 at $0.5 \mathrm{~A} \cdot \mathrm{g}^{-1}$ & 132 at $20 \mathrm{~A} \cdot \mathrm{g}^{-1}$ & 10000 cycles at $5 \mathrm{~A} \cdot \mathrm{g}^{-1} @ 97 \%$ & [4] \\
\hline Graphene/N-rich carbon & 229 at $1 \mathrm{~A} \cdot \mathrm{g}^{-1}$ & 196 at $10 \mathrm{~A} \cdot \mathrm{g}^{-1}$ & 10000 cycles at $2 \mathrm{~A} \cdot \mathrm{g}^{-1} @ 99.5 \%$ & {$[5]$} \\
\hline N-doped carbon foam & 280 at $1 \mathrm{~A} \cdot \mathrm{g}^{-1}$ & 185 at $40 \mathrm{~A} \cdot \mathrm{g}^{-1}$ & 10000 cycles at $5 \mathrm{~A} \cdot \mathrm{g}^{-1} @ 96.3 \%$ & [6] \\
\hline N-doped tubular carbon & 204 at $0.1 \mathrm{~A} \cdot \mathrm{g}^{-1}$ & 173 at $10 \mathrm{~A} \cdot \mathrm{g}^{-1}$ & 50000 cycles at $5 \mathrm{~A} \cdot \mathrm{g}^{-1} @ 91.5 \%$ & {$[7]$} \\
\hline N-doped carbon microtube & 309 at $1 \mathrm{~A} \cdot \mathrm{g}^{-1}$ & 220 at $10 \mathrm{~A} \cdot \mathrm{g}^{-1}$ & 10000 cycles at $1 \mathrm{~A} \cdot \mathrm{g}^{-1} @ 94 \%$ & {$[8]$} \\
\hline N-doped porous carbon & 292 at $1 \mathrm{~A} \cdot \mathrm{g}^{-1}$ & 200 at $20 \mathrm{~A} \cdot \mathrm{g}^{-1}$ & 10000 cycles at $1 \mathrm{~A} \cdot \mathrm{g}^{-1} @ 86 \%$ & [9] \\
\hline N-doped carbon nanorod & 271 at $0.5 \mathrm{~A} \cdot \mathrm{g}^{-1}$ & 175 at $20 \mathrm{~A} \cdot \mathrm{g}^{-1}$ & 10000 cycles at $5 \mathrm{~A} \cdot \mathrm{g}^{-1} @ 97 \%$ & {$[10]$} \\
\hline $3 \mathrm{D}$ porous carbon & 261 at $0.5 \mathrm{~A} \cdot \mathrm{g}^{-1}$ & 200 at $10 \mathrm{~A} \cdot \mathrm{g}^{-1}$ & 5000 cycles at 1 A·g ${ }^{-1} @ 96 \%$ & {$[11]$} \\
\hline N-doped porous carbon & 250 at $1.0 \mathrm{~A} \cdot \mathrm{g}^{-1}$ & 160 at $10 \mathrm{~A} \cdot \mathrm{g}^{-1}$ & 3000 cycles at 1 A·g ${ }^{-1} @ 97.3 \%$ & {$[12]$} \\
\hline N-doped carbon spheres & 301 at $0.2 \mathrm{~A} \cdot \mathrm{g}^{-1}$ & 210 at $5 \mathrm{~A} \cdot \mathrm{g}^{-1}$ & 5000 cycles at $5 \mathrm{~A} \cdot \mathrm{g}^{-1} @ 100 \%$ & {$[13]$} \\
\hline N-doped porous carbon & 252 at $1.0 \mathrm{~A} \cdot \mathrm{g}^{-1}$ & 189 at $15 \mathrm{~A} \cdot \mathrm{g}^{-1}$ & 10000 cycles at $15 \mathrm{~A} \cdot \mathrm{g}^{-1} @ 94 \%$ & {$[14]$} \\
\hline N-doped porous carbon & 334 at $1.0 \mathrm{~A} \cdot \mathrm{g}^{-1}$ & 215 at $20 \mathrm{~A} \cdot \mathrm{g}^{-1}$ & 10000 cycles at $20 \mathrm{mV} \cdot \mathrm{s}^{-1} @ 95.2 \%$ & {$[15]$} \\
\hline 3D graphene-like carbon & 252 at $1.0 \mathrm{~A} \cdot \mathrm{g}^{-1}$ & 168 at $50 \mathrm{~A} \cdot \mathrm{g}^{-1}$ & 5000 cycles at $50 \mathrm{mV} \cdot \mathrm{s}^{-1} @ 98 \%$ & {$[16]$} \\
\hline SiAlO-NC & 302 at $1 \mathrm{~A} \cdot \mathrm{g}^{-1}$ & $\begin{array}{l}218 \text { at } 20 \mathrm{~A} \cdot \mathrm{g}^{-1} \\
177 \text { at } 120 \mathrm{~A} \cdot \mathrm{g}^{-1}\end{array}$ & 20000 cycles at $20 \mathrm{mV} \cdot \mathrm{s}^{-1} @ 92 \%$ & This work \\
\hline
\end{tabular}

and high double-layer capacitance, owing to the hightemperature sintering process and the interaction between $\mathrm{Si}-\mathrm{O}-\mathrm{Si}$ network and aluminum oxide. On one hand, SiAlO-NC is prepared at high temperature $\left(1000{ }^{\circ} \mathrm{C}\right)$, which results in high electronic conductivity in the carbon material. On the other hand, the interaction between $\mathrm{Si}-\mathrm{O}-\mathrm{Si}$ network and aluminum oxide leads to high pore volume $\left(1.78 \mathrm{~cm}^{3} \cdot \mathrm{g}^{-1}\right)$, the hierarchical pore structure $(0.5-60 \mathrm{~nm})$ and $3 \mathrm{D}$ interconnected structure in SiAlO-NC, which is convenient for ions in the electrolyte to approach the active sites in the carbon material. The other part of the capacitance, $k_{2} v^{-1 / 2}$, originating from the pseudocapacitance is $\sim 70 \mathrm{~F} \cdot \mathrm{g}^{-1}$. Thus, this material shows the combination of pseudocapacitance and electric double-layer capacitance.

The currents at each potential are deconvoluted into currents proportional to $v$ and $v^{1 / 2}$ in the CV curves. The former is a capacitive $\mathrm{CV}$ loop, as shown in Fig. S11(b-c) ${ }^{[1]}$. Here, the shaded loop represents the capacitor-like charge storage. The fraction of capacitive capacitance $C_{\mathrm{c}}$ in the total capacitance $C_{\mathrm{t}}$ is calculated according to the shaded loop (Fig. S11(d)).

\section{References:}

[1] LIN T Q, CHEN I W, LIU F X, et al. Nitrogen-doped mesoporous carbon of extraordinary capacitance for electrochemical energy storage. Science, 2015, 350: 1508-1513.

[2] DEKA N, BARMAN J, KASTHURI S, et al. Transforming waste polystyrene foam into $\mathrm{N}$-doped porous carbon for capacitive energy storage and deionization applications. Appl. Surf. Sci., 2020, 511: 145576 .

[3] HUO S, LIU M, WU L, et al. Methanesulfonic acid-assisted synthesis of $\mathrm{N} / \mathrm{S}$ co-doped hierarchically porous carbon for high performance supercapacitors. J. Power Sources, 2018, 387: 81-90.

[4] ZHANG R, JING X, CHU Y, et al. Nitrogen/oxygen co-doped monolithic carbon electrodes derived from melamine foam for high-performance supercapacitors. J. Mater. Chem. A, 2018, 6: 17730-17739.

[5] CHEN Y, XIAO Z, LIU Y, et al. A simple strategy toward hierarchically porous graphene/nitrogen-rich carbon foams for high-performance supercapacitors. J. Mater. Chem. A, 2017, 5: 24178-24184.

[6] WANG Y, LIU Y, WANG D, et al. Free-standing honeycomb-like $\mathrm{N}$ doped carbon foam derived from coal tar pitch for highperformance supercapacitor. Appl. Surf. Sci., 2020, 506: 145014. 
[7] YUKSEL R, BUYUKCAKIR O, PANDA P K, et al. Necklace-like nitrogen doped tubular carbon 3D frameworks for electrochemical energy storage. Adv. Funct. Mater, 2020, 30: 1909725.

[8] LUO J D, ZHANG H, ZAHNG Z, et al. In-built template synthesis of hierarchical porous carbon microcubes from biomass toward electrochemical energy storage. Carbon, 2019, 155: 1-8.

[9] ZHU D, JIANG J, SUN D, et al. A general strategy to synthesize high-level N-doped porous carbons via schiff-base chemistry for supercapacitors. J. Mater. Chem. A, 2018, 6: 12334-12343.

[10] ZHENG L P, TANG B, DAI X C, et al. High-yield synthesis of $\mathrm{N}$-rich polymer-derived porous carbon with nanorod-like structure and ultrahigh $\mathrm{N}$-doped content for high-performance supercapacitors. Chemical Engineering Journal, 2020, 399: 125671.

[11] TONG X, ZHUO H, WANG S, et al. A new strategy to tailor the structure of sustainable 3D hierarchical porous N-self-doped carbons from renewable biomass for high-performance supercapacitors and $\mathrm{CO}_{2}$ capture. RSC Advances, 2016, 6: 34261-34270.
[12] WANG D H, CHEN Y, YANG H Q, et al. N-doped porous carbon anchoring on carbon nanotubes derived from ZIF-8/polypyrrole nanotubes for superior supercapacitor electrodes. Applied Surface Science, 2018, 457: 1018-1024.

[13] WANG T, SUN Y, ZHANG L L, et al. Space-confined polymerization: controlled fabrication of nitrogen-doped polymer and carbon microspheres with refined hierarchical architectures. Advanced Materials, 2019, 31: 1807876.

[14] HAO Y X, QIAN M, XU J J, et al. Porous cotton-derived carbon: synthesis, microstructure and supercapacitive performance. Journal of Inorganic Materials, 2018, 33(1): 93-99.

[15] QIAN M, WANG Z M, LI Z, et al. Sol-gel assisted chemical activation for nitrogen doped porous carbon. Microporous Mesoporous Materials, 2019, 286: 18-24.

[16] XU F, LIN T Q, BI H, et al. Graphene-like carbon with threedimensional periodicity prepared from organic-inorganic templates for energy storage application. Carbon, 2017, 111: 128-132. 